OPEN ACCESS

Edited by:

Yigit Kemal Demirel, University of Strathclyde,

United Kingdom

Reviewed by:

Jeanette Hammer Andersen, UiT The Arctic University of Norway,

Norway

${ }^{*}$ Correspondence:

Jessica Gomez-Banderas j.gomez-banderas.19@abdn.ac.uk

Specialty section:

This article was submitted to

Marine Biotechnology,

a section of the journal

Frontiers in Marine Science

Received: 20 January 2022 Accepted: 03 February 2022

Published: 24 February 2022

Citation:

Gomez-Banderas J (2022) Marine Natural Products: A Promising Source of Environmentally Friendly Antifouling

Agents for the Maritime Industries.

Front. Mar. Sci. 9:858757.

doi: 10.3389/fmars.2022.858757

\section{Marine Natural Products: A Promising Source of Environmentally Friendly Antifouling Agents for the Maritime Industries}

\author{
Jessica Gomez-Banderas ${ }^{1,2 *}$ \\ ${ }^{1}$ The National Decommissioning Centre, University of Aberdeen, Aberdeen, United Kingdom, ${ }^{2}$ Department of Chemistry, \\ Marine Biodiscovery Centre, University of Aberdeen, Aberdeen, United Kingdom
}

Biofouling in the marine environment refers to an unwanted build-up of marine organisms on subsea surfaces including harbor docks, hulls of ships and offshore installations. The first stage of marine fouling occurs as a microbial biofilm which forms via the aggregation of bacterial, algal, and fungal cells. This biofilm provides a favorable substrate for the larval settlement of larger organisms such as mussels, barnacles and hard corals which accumulate to uncontrollable extents, causing issues for the maritime industries. Since the ban of tributyltin (TBT) in 2008 by the International Maritime Organisation, alternative antifouling agents have been used such as algaecides and copper-based coatings. Recent studies are showing that these can accumulate in the marine environment and have toxic effects against non-target species. Marine microbes and invertebrates are known to be prolific producers of bioactive molecules, including antifouling active compounds. These compounds are often produced by marine organisms as a means of chemical defense to deter predators and prevent fouling of their own surfaces, making them a promising source of new antifouling agents. This article discusses the effects of biofouling on the maritime industries, the environmental dangers of currently used antifouling compounds and why natural products from marine organisms could be a source of environmentally friendly antifouling agents.

Keywords: biofouling, antifouling, decommissioning, shipping, renewable energy, oil and gas, marine natural products

\section{INTRODUCTION}

Biofouling in the marine environment can be described as an accumulation of marine organisms on subsea surfaces to undesirable extents. Marine bacteria quickly colonize submerged surfaces and aggregate to form microbial biofilms. These biofilms then attract the settlement of algal spores and the larvae of marine invertebrates such as barnacles, mussels, and hard corals (Figure 1). Microbial biofilms consist predominantly of bacteria, diatoms and an extracellular polymeric substance (EPS) matrix which is made up of polysaccharides, proteins, glycolipids, and extracellular DNA (e-DNA) 


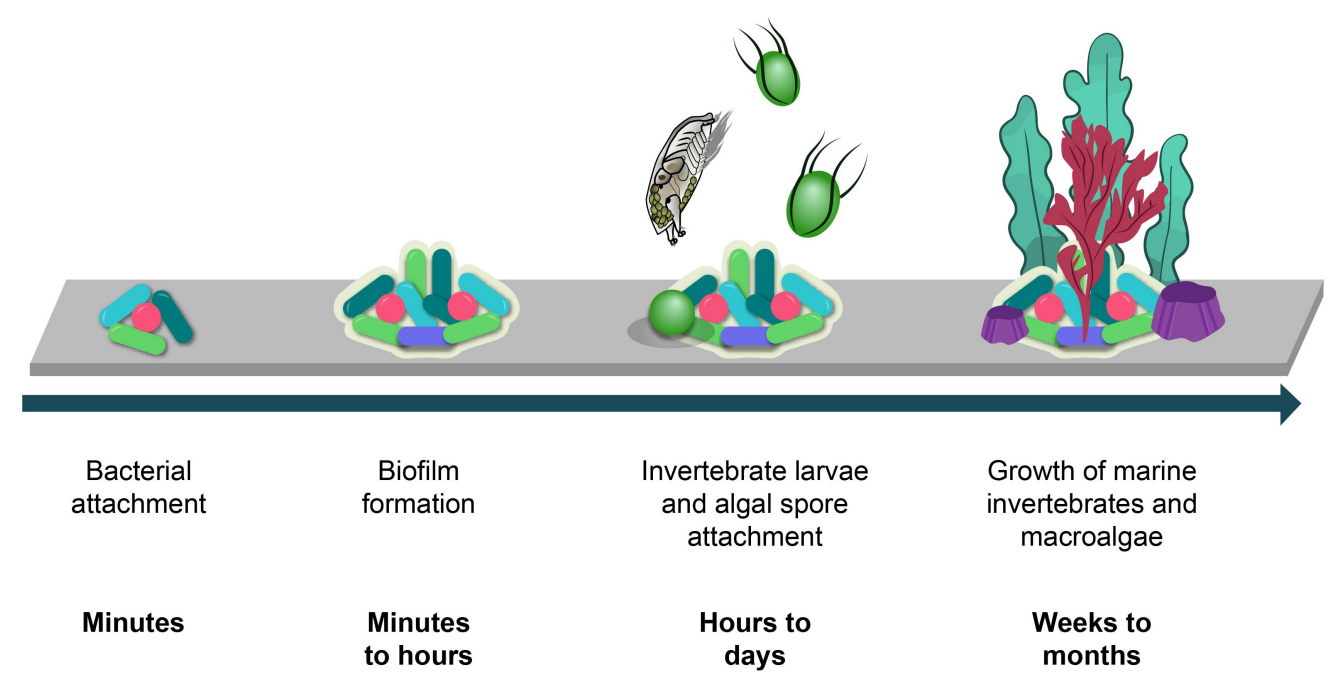

FIGURE 1 | Marine biofouling process timeline.

(Flemming, 2009). This EPS matrix allows biofilms to strongly adhere to surfaces through physicochemical interactions such as Van der Waals forces, hydrogen bonding and electrostatic forces (Mayer et al., 1999). Although these forces are generally weak, the overall combination of all these forces makes the biofilm mechanically stable. Quorum sensing (QS) is an additional mechanism which gives biofilms mechanical stability. This signaling system is used by bacteria to allow cells to communicate and aggregate for biofilm maturation and it is also the communication system behind luminescence and virulence (Miller and Bassler, 2001).

Through various settlement cues, marine biofilms encourage the settlement of marine invertebrate larvae and algal spores (Dobretsov and Rittschof, 2020) which mature and then grow in abundance. These organisms quickly colonize the entirety of subsea surfaces which is problematic for the maritime industries due to the increase in maintenance requirements and the corresponding financial losses. Antifouling (AF) coatings are commonly applied to subsea structures to prevent biofouling, however, many of the AF agents which are incorporated into these coatings have serious consequences on the marine environment highlighting the need for alternative, environmentally friendly solutions. This article highlights the negative impact biofouling has on maritime industries, the environmental challenges caused by currently used AF agents and the use of marine natural products as an alternative source of $\mathrm{AF}$ active agents.

\section{EFFECTS OF BIOFOULING ON MARITIME INDUSTRIES}

The accumulation of marine organisms on subsea structures is problematic for many maritime industries including the shipping, offshore oil and gas, and the offshore renewable energy sector. The effects caused by biofouling typically lead to economic losses for these industries as well as losses in structural integrity. Biofouling can also have serious ecological implications on marine biodiversity and there are ongoing debates regarding the creation of new ecosystems surrounding oil and gas structures and the subsequent destruction of these new ecosystems come the time of decommissioning.

\section{Shipping}

Biofouling of the hulls of ships by marine organisms results in an increase in drag, due to increased surface roughness (Farkas et al., 2018), which in turn leads to higher fuel costs (Schultz et al., 2011). A recent study by the International Maritime Organisation (2021) shows that even low amounts of biofouling on ships can lead to an increase in greenhouse gas emissions within the range of $20-25 \%$. This negatively contributes to worldwide concerns surrounding climate change therefore biofouling of ships should be prevented to help reduce harmful emissions. To effectively remove persistent fouling from the surfaces of ships, they must be dry-docked and scraped which is costly and time consuming for these companies. Additionally, fouling of ships can encourage the introduction of invasive and non-native species into ecosystems. As ships travel from one location to another, organisms which foul the ship's surface are transported to, and introduced into, ecosystems in which they do not belong which can be very damaging for these environments (Molnar et al., 2008). Didemnum vexillum is an example of an invasive sea-squirt species in British waters which was likely introduced via ships or recreational boats. This non-native species interferes with marine habitats by rapidly growing and forming "carpets" over native species, resulting in a smothering effect and preventing the growth of other native species (Marine Scotland, 2021).

\section{Oil and Gas/Decommissioning}

Biofouling of oil and gas structures is undesirable during the working life of installations and provides additional challenges 
at the time of decommissioning. Extensive build-up of marine organisms contributes to early aging and the need to replace and repair structures due to corrosion. Microbially induced corrosion (MIC), which involves anaerobic sulfate-reducing bacteria and aerobic iron-oxidizing bacteria within the biofilm layer (Li and Ning, 2019), is one of the main causes of corrosion in the offshore industry. To help prevent the buildup of biofouling, routine maintenance of subsea jackets of oil and gas rigs must be conducted which requires remote operating vehicles with cleaning attachments to carry out the work-adding additional operating costs. If biofouling is not removed, new ecosystems are formed surrounding oil and gas platforms (van Elden et al., 2019), however, this is unfavorable as these new ecosystems are quickly destroyed come the time of decommissioning when the structure is removed. Under the current Oslo-Paris Convention regulations (OSPAR Commission, 2013), oil and gas jackets must be removed during the decommissioning process and the jackets cannot be left in place as artificial reefs as per the "Rigs-to-Reefs" program which is implemented in the Gulf of Mexico, Brunei and Malaysia. Marine fouling can also add thousands of tons of additional weight to subsea structures (Hustoft and Gamblin, 1995) hence larger machinery are required to lift the structures out of place, resulting in further economic implications for these companies since they cannot be left in place to allow the new ecosystems to thrive.

\section{Offshore Renewables}

Similarly to the oil and gas industry, the offshore renewables sector is also negatively affected by biofouling. One of the main implications is that marine biofouling drastically lowers the lifespan of these systems (Yang et al., 2017). The colonization of renewable energy structures such as wind turbines and wave energy converters, impacts various engineering parameters which in turn affects the overall functionality and efficiency of these systems (Shi et al., 2012; Martinez-Luengo et al., 2017; Jahjouh, 2020; Arcigni et al., 2021). It is also essential that renewable energy structures are engineered to account for the additional weight from biofouling, however, this weight can be challenging to predict.

\section{CURRENTLY USED ANTIFOULING AGENTS AND THEIR ENVIRONMENTAL EFFECTS}

Antifouling active, chemical-based coatings have been used to prevent marine fouling since the 1800s when the first copper sulfide coating was manufactured by Bonnington Chemical Works, United Kingdom (Ronalds, 2019) to replace antifouling methods such as covering ship hulls with metal sheathing. When tributyltin (TBT)-based coatings were later introduced, they quickly became the most effective and commonly used AF solution until they were banned in 2008 by the International Maritime Organization. TBT is toxic to non-target species at low concentrations, notably the female sea snail, whose fertility is damaged when exposed to TBT (Gibbs et al.,
1991). Alternative AF agents are currently used in the marine industries, but recent studies highlight that these agents are not as "green" as they were once thought to be. Antifouling agents can also have devasting effects on ecosystems and marine biodiversity if they show toxicity towards marine wildlife. According to the Biocidal Products Regulation, an antifoulant must show high activity, low toxicity effects on target and non-target organisms and must not show unacceptable effects on the environment to be authorized as a new antifouling compound for commercial use (Biocidal Products Regulation, 2012). To understand the true impacts of introducing these compounds into the marine environment, long term monitoring is required, and the effects of these compounds are often not well understood until after many years of application. Current literature supports that many of the commonly used AF agents used are no longer suitable for use and should be replaced with alternative, non-toxic solutions (Figure 2).

\section{Seanine 211 (DCOIT)}

Seanine 211 is a globally used antifouling agent containing the biocidal ingredient DCOIT (1) which is effective against a wide range of fouling organisms. There are, however, concerns surrounding the use of this AF agent due to its inconsistent degradation properties and its toxic nature. For example, a study by Jacobson and Willingham (2000) states the half-life of Seanine 211 in seawater to be $24 \mathrm{~h}$, however, a review by Chen and Lam (2017) shows that different environmental factors affect Seanine 211 degradation, and its half-life can in fact range from $<1$ to 13.1 days. This shows that the degradation rates of Seanine 211 are variable and depend on many external factors. In addition, the biocidal agent, DCOIT, has been found to have comparable or higher toxicities than organotin toward marine bacterium Vibrio fischeri, crustacean Daphnia magna and freshwater green algae Selenastrum capricornotum (Fernández-Alba et al., 2002). It also exhibits comparable toxicity effects to triphenyltin on oyster embryos (Tsunemasa and Okamura, 2010) and is more toxic than tributyltinoxide when considering the development of sea urchins (Kobayashi and Okamura, 2002). Due to the similarities in toxicities between organotin species and DCOIT, the global use of Seanine 211 should be reconsidered and the importance of finding non-toxic alternatives is further validated.

\section{Irgarol 1051}

Irgarol 1051 (2) is another widely used biocide which is one of the least toxic to non-target species when compared against other antifouling agents and organotin (Fernández-Alba et al., 2002). Although it shows low toxicity effects, Irgarol 1051 is in fact classed as an environmental contaminant and has been found to persist in various marine environments all over the world (Konstantinou and Albanis, 2004). This AF agent has poor biodegradability which is reflected in its long half-lives of 100 and 200 days in seawater and freshwater, respectively (Ciba Geigy, 1995) and could accumulate in sediments according to its high octanol/water coefficient of $\log \mathrm{K}_{\mathrm{ow}}=3.95$ (Bard and Pedersen, 1992). Although the 
<smiles>CCCCCCCCn1sc(Cl)c(Cl)c1=O</smiles>

(1)<smiles>CCCCCCCCC1C=CC(=O)O1</smiles>

(4)<smiles>CSc1nc(NC2CC2)nc(NC(C)(C)C)n1</smiles>

(2)<smiles>[R]C(Br)=C1OC(=O)C(C([R])CCC)=C1Br</smiles><smiles>CN(C)C(=O)Nc1ccc(Cl)c(Cl)c1</smiles>

(3)<smiles>CC(C)[C@H]1CC=C[C@@H]2[C@H]1CC[C@@]1(C)[C@@H](Br)CC[C@@](C)(O)[C@H]21</smiles>

(6)<smiles>CC/C(Br)=C\C=C\[C@@H](O)[C@H](Br)[C@H]1OC(C=C=CBr)C[C@H]1O</smiles>

(7)<smiles>COc1ccc(C/C(=N/O)C(=O)NCCc2cc(Br)c(OCCCN(C)C)c(Br)c2)cc1Br</smiles>

(9)<smiles>COc1c(Br)cc(/C=C/C(=O)N(C)CCc2cc(Br)c(OCN)c(Br)c2)cc1Br</smiles>

(11)<smiles>COc1c(Br)cc(C/C(=N/O)C(=O)NCCc2c[nH]c(=N)[nH]2)cc1Br</smiles>

(8)

(10)<smiles>COc1c(Br)cc(/C=C/C(=O)NCCc2nc(N)[nH]c2C/C(=N\O)C(=O)NCCc2cc(Br)c(OCCCN)c(Br)c2)cc1Br</smiles>

FIGURE 2 | Structures of currently used AF agents (1-3) and AF active marine natural products (4-12)

degradation time of Irgarol 1051 is slow, the degradation product has been found in environmental samples and is moderately toxic toward $V$. fisheri, and four crustaceans: D. magna,
Daphnia pulex, Thamnocephalus platyurus, and Artemia salina. It is also highly toxic toward green algae $S$. capricornutum (Okamura et al., 2000). 


\section{Diuron}

Diuron, also known as DCMU (3), is an algaecide, herbicide and PSII inhibitor. Because of its detrimental environmental effects, Bulgaria is the only EU state member which permits its use but diuron continues to be used in other parts of the world (Lewis et al., 2016). When compared with other herbicides, diuron effects the growth rate of non-target diatom Chaetoceros muelleri at very low concentrations (Thomas et al., 2020) and it has also been shown to be moderately toxic toward fish and slightly toxic to aquatic invertebrates (Giacomazzi and Cochet, 2004). The degradation product of diuron, 3-4dichloroaniline, shows higher toxicity against different marine species including various fish, bacteria, and microalgae amongst others (Giacomazzi and Cochet, 2004).

\section{ANTIFOULING ACTIVE MARINE NATURAL PRODUCTS}

Marine organisms such as bacteria, fungi and invertebrates are producers of interesting and complex compounds exhibiting a wide range of bioactivities. These organisms are most commonly explored for compounds with use as therapeutic drugs against cancerous tumors, viruses, microbial infections, and other ailments. Just under 30 marine natural products (MNPs), including derivatives, are currently in clinical trials and 17 compounds have been approved for use by the FDA to date (Marine Pharmacology, 2021). With the emergence of new viruses and the growing resistance of infectious bacterial strains, it is important to keep looking to these alternative sources for new drugs.

Alongside investigating MNPs for their medicinal properties, there is a growing interest in understanding the chemical ecology of our marine ecosystems and the ways in which marine organisms interact with one another. This can be done by studying the chemical profiles of the metabolites produced by these organisms, the mechanisms by which they are biosynthesized and discovering the "whys" of their production. As a means of chemical defense, marine organisms can produce and excrete metabolites to deter predators, to compete with other organisms and to prevent fouling of their outer surfaces, in the case of marine invertebrates and macroalgae (Puglisi et al., 2019). A recent review by Liu et al. (2021) reports that $182 \mathrm{AF}$ active compounds were isolated from marine organisms between August 2014 and May 2020 and in contrast to the 1,490 new MNPs reported in 2019 alone (Carroll et al., 2021), this figure is very small. This is an indicator that $\mathrm{AF}$ active compounds from marine sources are under-explored and that there are many more compounds with AF activity to be discovered. Following the discovery of AF active MNPs, analogs can be synthesized and tested to determine whether the activity can be increased by altering the structure of the compound. If the compounds are isolated from marine invertebrates or algae, the ideal route for mass production would be large scale synthesis. In the case of AF natural products from microbial origins, these compounds can often be sustainably produced via biotransformation processes which can also help to reduce carbon emissions.

\section{Butenolides}

The butenolides, a class of natural products containing a 2furanone moiety, were first discovered to have potent AF activity when they were isolated from a marine Streptomyces strain after the bacterium showed AF activity during preliminary bioassay testing (Xu et al., 2010). The isolated compounds, alongside some previously isolated butenolides, show AF activity against the settlement of marine foulers and it was found that the 2 -furanone moiety is responsible for the bioactivity. A modified butenolide (4) has since been synthesized which, when incorporated into a paint and tested in the field, exhibits more potent inhibition activity (lowest $\mathrm{EC}_{50}=0.02 \mu \mathrm{g} / \mathrm{mL}$ ) against the settlement of common fouling organisms whilst maintaining low toxicity. The butenolide compounds are a notable success story as this modified compound was patented for use as an antifouling agent (Peiyuan et al., 2017). Additionally, a study by Chen et al. (2015) found the half-life of a butenolide compound to be 0.5 days whereas DCOIT, the active compound in commonly used SeaNine $211 \mathrm{AF}$ agent, had still not degraded after 4 days. Due to the quick degradation of butenolide compounds, their efficacy at low concentrations and low toxicity, they are a perfect example of marine natural product inspired AF agents with environmentally friendly potential.

\section{Halogenated Compounds From Macroalgae}

Algal extracts have been shown to exhibit antifouling activity against marine bacteria (Hellio et al., 2001) with macroalgae being the main producer of antifouling active compounds, including some interesting, halogenated compounds (Dahms and Dobretsov, 2017). Halogenated furanones from the red alga Delisea pulchra are an example of AF active compounds with activity against both micro and macrofoulers. D. pulchra is a macroalgae which does not show fouling on its outer surface and four surface furanones (5) have been isolated which show AF activity against ecologically relevant marine organisms (Dworjanyn et al., 2006). These compounds are an example of chemical defense compounds produced by this species to deter settling of organisms on the algal surface via quorum sensing inhibition by altering the EPS matrix produced by the bacteria hence inhibiting biofilm growth. Another red alga, Sphaerococcus coronopifolius, produces various brominated terpenes with $\mathrm{AF}$ activity, notably bromosphaerol (6) which shows promising results by inhibiting the settlement of the barnacle Amphibalanus amphitrite at an $\mathrm{EC}_{50}$ of $0.23 \mathrm{mg} / \mathrm{L}$ whilst showing low toxicity effects $\left(\mathrm{LC}_{50}>100 \mathrm{mg} / \mathrm{L}\right)$ (Piazza et al., 2010). Laurencia sp. also produces AF active compounds such as bromoallenecontaining natural products including omaezallene (7) and its corresponding congeners, which are also active against the settlement of A. amphitrite larvae (Umezawa et al., 2014).

\section{Bromotyrosine Containing Compounds}

In addition to macroalgae, marine sponges also biosynthesize halogenated compounds with antifouling properties. Amongst these compounds are bromotyrosine derivatives which have been isolated from various sponge species and are active 
against both micro and macrofoulers. Ianthelline (8) is an example of a bromotyrosine containing compound which was originally isolated from the Caribbean sponge Ianthella ardis (Litaudon and Guyot, 1986) and then later isolated from an Arctic sponge and tested for its AF bioactivity. Hanssen et al. (2014) found that ianthelline shows varying degrees of AF activity against marine bacterial growth, bacterial adhesion, and in larval settlement assays using B. improvisus cyprids an $\mathrm{IC}_{50}$ of $3 \mu \mathrm{g} / \mathrm{mL}$ was recorded. Low toxicity was also reported at the highest concentration of $20 \mu \mathrm{g} / \mathrm{mL}$. Ianthelline has been isolated from many sponge species and has been shown to be active in inhibiting bacterial attachment of bacterial species associated with the sponge Ailochroia crassa (Kelly et al., 2005). This could indicate the ecological role of ianthelline as a defense compound produced to prevent bacterial surface colonization, again highlighting the importance of exploring marine invertebrate chemical defense compounds as new sources of antifouling agents. Additionally, several bastadin derivatives isolated from Ianthella basta, aplysamine-2 (9) from Pseudoceratina purpurea and psammaplin A (10) isolated from Aplysinella rhax have been found to show larval settlement inhibition activity of $B$. improvisus at low concentrations (Ortlepp et al., 2007). In this study, it was found that the oxime moiety was an important functional group for producing the antifouling activity in addition to the bromine atoms. Aplyzanzine E (11) and two bromine containing 2-aminoimidazolic compounds (12) isolated from Pseudoceratina sp. show AF activity against three strains of marine bacteria, three strains of microalgae and also inhibited the quorum sensing behavior of Vibrio harveyi (Tintillier et al., 2020).

\section{CONCLUDING REMARKS}

Marine biofouling is a significant issue for the maritime industries due to the economic losses associated with biofouling induced structural degradation and increased fuel costs. The ecological implications caused by biofouling are also unfavorable as they can be detrimental to marine biodiversity. Although

\section{REFERENCES}

Arcigni, F., Abhinav, K., Collu, M., and Venturini, M. (2021). Analysis of tripod supported offshore wind turbines under conditions of marine growth. Ocean Eng. 220:108441. doi: 10.1016/j.oceaneng.2020.108441

Bard, J., and Pedersen, A. (1992). Ecotoxicological Evaluation of the Antifouling Compound 2-(Tert-Butylamino)-4-(Cyclopropylamino)-6-(Methylthio)-1, 3, 5Triazine, Irgarol. Solna: Swedish National Chemicals Inspectorate (KEMI).

Biocidal Products Regulation (2012). Biocidal Products Regulation. https:// echa.europa.eu/regulations/biocidal-products-regulation/legislation (accessed December 22, 2021).

Carroll, A., Copp, B., Davis, R., Keyzers, R., and Prinsep, M. (2021). Marine natural products. Natural Product Reports 38, 362-413. doi: 10.1039/d0np00089b

Chen, L., and Lam, J. (2017). SeaNine 211 as Degradation kinetics of a potent antifouling agent, butenolide, under various environmental conditions antifouling biocide: a coastal pollutant of emerging concern. J. Environ. Sci. 61, 68-79. doi: 10.1016/j.jes.2017.03.040

Chen, L., Xu, Y., Wang, W., and Qian, P. (2015). Degradation kinetics of a potent antifouling agent, butenolide, under various environmental it is important that the attachment of marine organisms on subsea structures is prevented, the application of currently used antifouling agents should be reconsidered due to the high number of studies supporting their negative impact on the marine environment. With the success of butenolide and the promising AF activity and low toxicities of other classes of MNPs, it is important that research into the discovery of new AF-active natural products continues to be explored. Compounds produced by marine microbes, macroalgae, sponges, and corals which grow in different global environments, including extreme environments, should be prioritized and halogenated compounds, such as brominated compounds, should also be targeted due to the high proportion of AF active MNPs containing halogenated atoms. It is important, however, to test these compounds for their toxicity against non-target species to ensure they are safe for use as AF agents. MNPs are a very promising source of inspiration for synthesizing new and environmentally friendly AF agents and are the way forward in preventing the many environmental issues caused by the currently used AF compounds.

\section{AUTHOR CONTRIBUTIONS}

JG-B developed the concept for the review and wrote all sections.

\section{FUNDING}

This research project was funded by the Net Zero Technology Centre and the University of Aberdeen, through their partnership in the UK National Decommissioning Centre (Grant RG15115-10).

\section{ACKNOWLEDGMENTS}

I would like to thank Prof. Marcel Jaspars for his insight during the drafting process and Sarah Dickie for illustrating Figure 1.

conditions. Chemosphere 119, 1075-1083. doi: 10.1016/j.chemosphere.2014. 09.056

Ciba Geigy (1995). Irgarol 1051 Material Safety Data Sheet 6389501 Ciba Geigy. Basel: Additives Division.

Dahms, H., and Dobretsov, S. (2017). Antifouling compounds from marine macroalgae. Mar. Drugs 15, 1-16. doi: 10.3390/md15090265

Dobretsov, S., and Rittschof, D. (2020). Love at first taste: induction of larval settlement by marine microbes. Int. J. Mol. Sci. 21:731. doi: 10.3390/ ijms21030731

Dworjanyn, S., de Nys, R., and Steinberg, P. (2006). Chemically mediated antifouling in the red alga Delisea pulchra. Mar. Ecol. Progr. Series 318, 153-163. doi: $10.3354 /$ meps 318153

Farkas, A., Degiuli, N., and Martiæ, I. (2018). Towards the prediction of the effect of biofilm on the ship resistance using CFD. Ocean Eng. 167, $169-186$.

Fernández-Alba, A., Hernando, M., Piedra, L., and Chisti, Y. (2002). Toxicity evaluation of single and mixed antifouling biocides measured with acute toxicity bioassays. Analytica Chim. Acta 456, 303-312. doi: 10.1016/s00032670(02)00037-5 
Flemming, H. (2009). "Why microorganisms live in biofilms and the problem of biofouling," in Marine and Industrial Biofouling, eds H. Flemming, K. Cooksey, P. Murthy, and R. Venkatesan (Berlin: Springer), 3.

Giacomazzi, S., and Cochet, N. (2004). Environmental impact of diuron transformation: a review. Chemosphere 56:1021. doi: 10.1016/j.chemosphere. 2004.04.061

Gibbs, P., Bryan, G., and Pascoe, P. (1991). TBT-induced imposex in the dogwhelk, Nucella lapillus: geographical uniformity of the response and effects. Mar. Environ. Res. 32, 79-87. doi: 10.1016/0141-1136(91)90035-7

Hanssen, K., Cervin, G., Trepos, R., Petitbois, J., Haug, T., Hansen, E., et al. (2014). The bromotyrosine derivative ianthelline isolated from the arctic marine sponge Stryphnus fortis inhibits marine micro- and macrobiofouling. Mar. Biotechnol. 16, 684-694. doi: 10.1007/s10126-014-9583-y

Hellio, C., De La Broise, D., Dufossé, L., Le Gal, Y., and Bourgougnon, N. (2001). Inhibition of marine bacteria by extracts of macroalgae: potential use for environmentally friendly antifouling paints. Mar. Environ. Res. 52, 231-247. doi: 10.1016/s0141-1136(01)00092-7

Hustoft, R., and Gamblin, R. (1995). Preparing for Decommissioning of the Heather Field [Conference Paper]. Aberdeen: SPE Offshore Europe.

International Maritime Organisation (2021). Impact of Ships' Biofouling on Greenhouse Gas Emissions. https://wwwcdn.imo.org/localresources/en/ MediaCentre/Documents/Biofouling\%20report.pdf (accessed February 2, 2022).

Jacobson, A., and Willingham, G. (2000). Sea-nine antifoulant: an environmentally acceptable alternative to organotin antifoulants. Sci. Total Environ. 258, $103-$ 110. doi: 10.1016/s0048-9697(00)00511-8

Jahjouh, M. (2020). The effect of marine growth and damage severity on the modal parameters of offshore wind turbine supporting structures: an experimental study. J. Vibroeng. 23, 407-418. doi: 10.21595/jve.2020.21429

Kelly, S., Garo, E., Jensen, P., Fenical, W., and Pawlik, J. (2005). Effects of Caribbean sponge secondary metabolites on bacterial surface colonization. Aquatic Microb. Ecol. 40, 191-203. doi: 10.3354/ame040191

Kobayashi, N., and Okamura, H. (2002). Effects of new antifouling compounds on the development of sea urchin. Mar. Pollut. Bull. 44, 748-751. doi: 10.1016/ s0025-326x(02)00052-8

Konstantinou, I., and Albanis, T. (2004). Worldwide occurrence and effects of antifouling paint booster biocides in the aquatic environment: a review. Environ. Int. 30, 235-248. doi: 10.1016/s0160-4120(03)00176-4

Lewis, K. A., Tzilivakis, J., Warner, D., and Green, A. (2016). An international database for pesticide risk assessments and management. Hum. Ecol. Risk Assessment: Int. J. 22, 1050-1064. doi: 10.1080/10807039.2015.1133242

Li, Y., and Ning, C. (2019). Latest research progress of marine microbiological corrosion and bio-fouling, and new approaches of marine anti-corrosion and anti-fouling. Bioactive Mater. 4:190. doi: 10.1016/j.bioactmat.2019.04.003

Litaudon, M., and Guyot, M. (1986). Ianthelline, a new derivative of 3, 5dibromo-tyrosine isolated from the sponge Ianthella-ardis from the Bahamas. Tetrahedron Lett. 27, 4455-4456. doi: 10.1016/s0040-4039(00)84977-1

Liu, L., Wu, C., and Qian, P. (2021). Marine natural products as antifouling molecules - a mini-review (2014-2020). Biofouling 36, 1210-1226. doi: 10.1080/ 08927014.2020 .1864343

Marine Pharmacology (2021). Clinical Pipeline. https://www.marinepharmacology. org/ (accessed December 22, 2021).

Marine Scotland (2021). The Smothering Impact of Didemnum vexillum. https://blogs.gov.scot/marine-scotland/2021/05/28/the-smothering-impactof-didemnum-vexillum/ (accessed December 22, 2021).

Martinez-Luengo, M., Causon, P., Gill, A. B., and Kolios, A. J. (2017). "The effect of marine growth dynamics in offshore wind turbine support structures," in Progress in the Analysis and Design of Marine Structures, eds C. Soares and Y. Garbatov (Boca Raton, FL: CRC Press/Balkema), 889-898.

Mayer, C., Moritz, R., Kirschner, C., Borchard, W., Maibaum, R., Wingender, J., et al. (1999). The role of intermolecular interactions: studies on model systems for bacterial biofilms. Int. J. Biol. Macromol. 26, 3-16. doi: 10.1016/s01418130(99)00057-4

Miller, M., and Bassler, B. (2001). Quorum sensing in bacteria. Annu. Rev. Microbiol. 55, 165-199. doi: 10.1146/annurev.micro.55.1.165

Molnar, J., Gamboa, R., Revenga, C., and Spalding, M. (2008). Assessing the global threat of invasive species to marine biodiversity. Front. Ecol. Environ. 6:485-492. doi: 10.1890/070064

Okamura, H., Aoyama, I., Liu, D., Maguire, R. J., Pacepavicius, G., and Lau, Y. L. (2000). Fate and ecotoxicity of the new antifouling compound Irgarol 1051 in the aquatic environment. Water Res. 34, 3523-3530. doi: 10.1016/s00431354(00)00095-6

Ortlepp, S., Sjögren, M., Dahlström, M., Weber, H., Ebel, R., Edrada, R., et al. (2007). Antifouling activity of bromotyrosine-derived sponge metabolites and synthetic analogues. Mar. Biotechnol. 9, 776-785. doi: 10.1007/s10126-0079029-x

OSPAR Commission (2013). OSPAR Guidelines on Artificial Reefs in relation to Living Marine Resources, Pub. L. No. Agreement 2013-03, Adopted in Bonn, Germany in June 2012. http:/www.mapama.gob.es/es/costas/temas/ proteccion-medio-marino/OSPAR_Artificial (accessed 22 December, 2021).

Peiyuan, Q., Chunfeng, M., and Yongxin, L. (2017). Chinese Patent No CN106700787A.

Piazza, V., Roussis, V., Garaventa, F., Greco, G., Smyrniotopoulos, V., Vagias, C., et al. (2010). Terpenes from the Red Alga Sphaerococcus coronopifolius inhibit the settlement of barnacles. Mar. Biotechnol. 13, 764-772. doi: 10.1007/s10126010-9337-4

Puglisi, M., Sneed, J., Ritson-Williams, R., and Young, R. (2019). Marine chemical ecology in benthic environments. Nat. Prod. Rep. 36, 410-429. doi: 10.1039/ c8np00061a

Ronalds, B. (2019). Bonnington chemical works (1822-1878): pioneer coal tar company. Int. J. Hist. Eng. Technol. 89:82. doi: 10.1080/17581206.2020.1787807

Schultz, M. P., Bendick, J. A., Holm, E. R., and Hertel, W. M. (2011). Economic impact of biofouling on a naval surface ship. Biofouling 27, 87-98.

Shi, W., Park, H., Baek, J., Kim, C., Kim, Y., and Shin, H. (2012). Study on the marine growth effect on the dynamic response of offshore wind turbines. Int. J. Precision Eng. Manufacturing 13, 1167-1176. doi: 10.1007/s12541-0120155-7

Thomas, M., Flores, F., Kaserzon, S., Reeks, T., and Negri, A. (2020). Toxicity of the herbicides diuron, propazine, tebuthiuron, and haloxyfop to the diatom Chaetoceros muelleri. Sci. Rep. 10:19592. doi: 10.1038/s41598-02076363-0

Tintillier, F., Moriou, C., Petek, S., Fauchon, M., Hellio, C., Saulnier, D., et al. (2020). Quorum sensing inhibitory and antifouling activities of new bromotyrosine metabolites from the polynesian sponge Pseudoceratina $n$. $s p$. Mar. Drugs 18:272. doi: 10.3390/md18050272

Tsunemasa, N., and Okamura, H. (2010). Effects of organotin alternative antifoulants on oyster embryo. Arch. Env. Contamination Toxicol. 61, 128-134. doi: 10.1007/s00244-010-9598-y

Umezawa, T., Oguri, Y., Matsuura, H., Yamazaki, S., Suzuki, M., Yoshimura, E., et al. (2014). Omaezallene from Red Alga Laurencia sp.: structure elucidation, total synthesis, and antifouling activity. Angewandte Chemie Int. Edn. 53, 3909-3912. doi: 10.1002/anie.201311175

van Elden, S., Meeuwig, J., Hobbs, R., and Hemmi, J. (2019). Offshore oil and gas platforms as novel ecosystems: a global perspective. Front. Mar. Sci. 6:548. doi: 10.3389/fmars.2019.00548

Xu, Y., He, H., Schulz, S., Liu, X., Fusetani, N., Xiong, H., et al. (2010). Potent antifouling compounds produced by marine Streptomyces. Bioresour. Technol. 101, 1331-1336. doi: 10.1016/j.biortech.2009.09.046

Yang, S., Ringsberg, J., Johnson, E., and Hu, Z. (2017). Biofouling on mooring lines and power cables used in wave energy converter systems-Analysis of fatigue life and energy performance. Appl. Ocean Res. 65, 166-177. doi: 10.1016/j.apor. 2017.04.002

Conflict of Interest: The author declares that the research was conducted in the absence of any commercial or financial relationships that could be construed as a potential conflict of interest.

Publisher's Note: All claims expressed in this article are solely those of the authors and do not necessarily represent those of their affiliated organizations, or those of the publisher, the editors and the reviewers. Any product that may be evaluated in this article, or claim that may be made by its manufacturer, is not guaranteed or endorsed by the publisher.

Copyright (c) 2022 Gomez-Banderas. This is an open-access article distributed under the terms of the Creative Commons Attribution License (CC BY). The use, distribution or reproduction in other forums is permitted, provided the original author(s) and the copyright owner(s) are credited and that the original publication in this journal is cited, in accordance with accepted academic practice. No use, distribution or reproduction is permitted which does not comply with these terms. 